\title{
吹き付けアモサイトの無害化
}

\author{
武田はやみ·橋本 忍 · 奥田篤史 ${ }^{*} \cdot$ 本多沢雄 · 淡路英夫 · 福田功一郎 \\ 名古屋工業大学環境材料工学科, 466-8555 名古屋市昭和区御器所町 \\ *株式会社富士清空工業所, 500-8474 岐阜市加納本町 6-18
}

\section{Detoxification of Sprayed Amosite}

\author{
Hayami TAKEDA, Shinobu HASHIMOTO, Atsushi Okuda*, Sawao HONDA, \\ Hideo AWAJI and Koichiro FUKUDA
}

Department of Environmental and Materials Engineering, Nagoya Institute of Technology, Gokiso-cho, Showa-ku, Nagoya-shi 466-8555 *Fuji Seiku Kogyosho Corporation. Ltd., 6-18, Kanou Honmachi Gifu-shi 500-8474

\begin{abstract}
According to XRD analysis, when sprayed amosite was heated at over $900^{\circ} \mathrm{C}$ for $3 \mathrm{~h}$, amosite crystal was not detected in the sample. In contrast, a part of the needlelike amosite grains were not detected in the sprayed amosite using a phase-contrast microscope analysis after heating at $500^{\circ} \mathrm{C}$ for $3 \mathrm{~h}$. Then the color of the needlelike amosite grains changed to red, because $\mathrm{Fe}_{2} \mathrm{O}_{3}$ (hematite) was precipitated at the surface of the amosite grains. The grindability of the needlelike amosite grains was improved with an increase of the heating temperature. When the sprayed amosite was heated at $1100^{\circ} \mathrm{C}$ for $3 \mathrm{~h}$, a fine powder with under aspect ratio of 3 was obtained after grinding.

[Received May 31, 2007; Accepted July 19, 2007]
\end{abstract}

Key-words : Asbestos, Amosite, Heat treatment, Mechanical grinding, Detoxification technique, Phase-contrast microscope

\section{1. 緒 言}

2006年 9 月 1 日, 厚生労働省が管轄する労働安全衛生法施行 令の改正抢よび関連する石綿障害予防規則の改正とその施行に より，工業製品にアスベストが含まれるという規定を，それま での「緘維強化セメント板」など特定の10品目に対して 1 質量 \%を超えて含有するものという条件から，全工業製品に対して 0.1 質量\%を超える量が含まれる場合にまで引き下げられた.

この 0.1 質量\%という数值は, 通常の科学分析手法での検出限 界を現したものと受け止めることができ，「原則禁止」から実 質的なアスベストの「全面禁止」の措置が打ち出された法令々 捉えることができる.

それより先立った2006年の 3 月末に, 経済産業省が JIS A 1481：2006を制定し，アスベストの含有条件について，位相差 顕微鏡による分散染色法による評価で「アスペクト比（長さ/ 径）が 3 以上の繊維状粒子で， 3000 計数中 4 粒子以上アスベス 卜繊維粒子が含まれる場合」とした。この条件は実質的に0.1 質量\%をアスベストの含有規定とみることができる，したがっ て，現在この JIS 規格による検出規定がそのままアスベストの 含有評価方法として適用されている.

著者らは，主に 3 種類あるアスベストの一つである蛇紋石族 系のクリソタイルについて，それを $1000^{\circ} \mathrm{C} て ゙ 3$ 時間加熱する と,この JIS 規格に基づく位相差顕微鏡による評価では検出さ れなくなること, すなわち無害化されることを明らかにした1). 一方，角閃石族系のクロシドライトは， $500^{\circ} \mathrm{C}$ 低温で加熱さ れた場合，XRD 分析ではクロシドライトが検出されたが，位 相差顕微鏡では，クロシドライト粒子を検出できなくなること が判明した2).

本研究は, クロシドライトと同じ角閃石族系に属するアモサ イトについて，その加熱処理がアモサイト結晶相抢よびその形 態に与える変化，被粉砕性に与える影響，およびアモサイト結 晶の検出のための位相差顕微鏡評価に与える影響について明ら かにした. 現在, アスペクト比が 3 以上のアスベスト粒子は危
険と診断される厳しい規定が適用されているので, アモサイト の被粉砕性の評価は，このような規定を満たすことができるか どうかを判断するために行った．さらに，この被粉砕性の評価 は，無害化処理後の物質の割業原料など 2 次資源として活用す ることの指標にもなる，以上の結果から，著者らが提唱するク リソタイルを $1000^{\circ} \mathrm{C}$ 程度で加熱し粉砕することにより無害化す る「低温加熱粉研処理法」(1) 5) 角閃石族系のアスベストにも 適用し統一した「アスベスト」の処理条件の確立を目指す。

\section{2. 実験方法}

実際に吹き付けられていて撤去されたアスベスト廃棄物を, 無害化研究用試料として入手した. 厚生労働省の石綿則による 撤去前の外部機関による調査で, アスベストの種類はアモサイ 卜 $\left(\left(\mathrm{Mg}<\mathrm{Fe}^{2+}\right)_{7} \mathrm{Si}_{8} \mathrm{O}_{22}(\mathrm{OH})_{2}\right)$ と判定されたものである. その 概観は, 灰褐色繊維状粒子と結合材として用いられている死色 のセメント粒子であった.

始めに，この試料の走査型電子顕微鏡（SEM）による微細組 織観察を行なった。また粉末 X 線回折 (XRD) 分析によりア スベストの種類を確認した。さらにアモサイトの微量測定を JIS A 1481：2006に基づく位相差顕微鏡を用いる分散染色法に

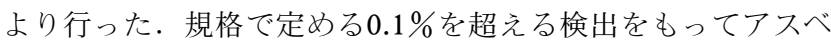
ストを含むものとした．その詳しい方法はクリソタイルの無害 化実験を行った前報1 ${ }^{1}$ を参照されたい。たたし，この浸液によ る評価では,アモサイト粒子は屈折率 : $N_{\mathrm{D}}^{25^{\circ} \mathrm{C}}=1.680$ の場合に は桃色に，1.700の場合には青色に呈色する.

吹き付けアモサイトの加熱による変化を調べた，吹き付けア

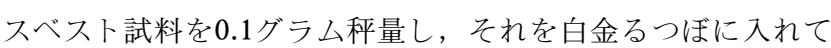
電気炉で加熱した。昇温速度は $600^{\circ} \mathrm{C} / \mathrm{h}$ とし， $500^{\circ} \mathrm{C}$ から 1400 ${ }^{\circ} \mathrm{C}$ の各温度で 3 時間保持後, 炉の電源を切って自然冷却させ た．加熱に伴うアモサイト結晶の変化をXRD 分析により調べ た．引き続いて加熱した吹き付けアモサイトを乳鉢でより丁寧 に (長時間) 粉砕し, その被粉砕性を詳しく調べた. その条件 


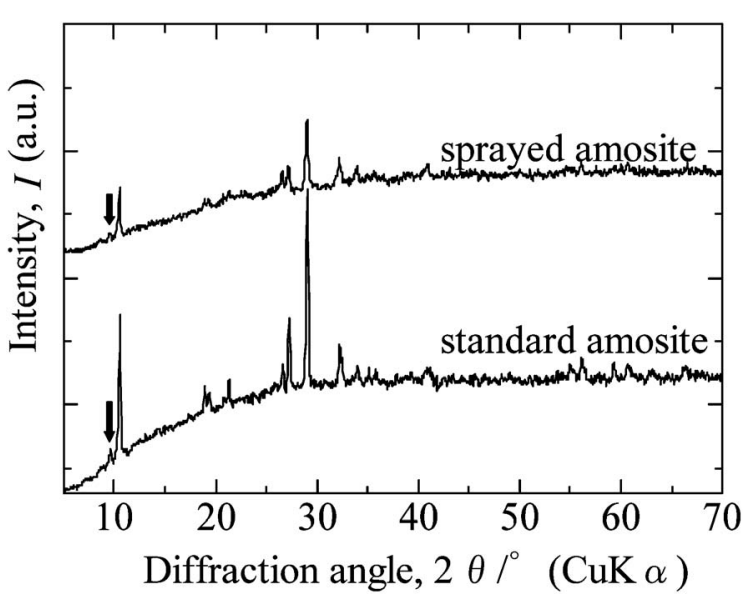

Fig. 1. XRD patterns of sprayed amosite and standard amosite (JAWE231).

はクリソタイルの実験の場合とほぼ同じで3),4), 加熱試料約 0.05 グラムを直径 8 センチの窒化珪素製乳鉢に入れ, 乳鉢と乳 棒の接点に常時 1 ～2 キログラムの荷重を印加しながら毎秒 1 ２回の回転速度で300秒間粉砕した. 加熱した吹き付けア モサイト試料, およびそれを乳鉢で粉砕した試料の微細組織を SEM で観察した。この場合，比較のために未加熱処理の試料 も乳鉢で粉砕し, その微細組織を観察した. 最後に, 加熱後の 吹き付けアモサイト試料に対して JIS 法による位相差顕微鏡で の分析評価を行なった。

\section{3. 結果と考察}

3.1 加熱変化

1975年に吹き付けアスベストの原則禁止が打ち出される前 は，一般に吹き付けアスベスト中のアスベスト含有率は60７0 質量\%と高く，その他に結合材のセメントや骨材，さらには発 泡剂（Al 粉末など）などが加えられていた。用いた吹き付け アスベスト試料をXRD 分析した結果を図 1 に示した。今日ま で信頼性が高いアモサイトのXRD 回折図形が公表されていな いので, (社) 日本作業環境測定協会が提供しているアモサイト 標準試料 (JAWE231) のXRD 分析結果も同時に示した.アモ サイトとクロシドライトの X 線回折パターンは非常に似てい るが，アモサイトの場合，図 1 中に矢印で示した $2 \theta=9.6^{\circ}$ 付近 の回折線をもって特定できる.この吹き付けアスベスト試料の $\mathrm{X}$ 線回折パターンは標準試料とよく一致し，アモサイトと同定 された.

図 2 にSEMによるこの吹き付けアモサイトの微細組織観察 結果を示した．SEM写真からセメント粒子もところどころに 観察されたが，主にアモサイトの緎維状粒子であった。このア モサイト粒子は，クリソタイル粒子 ${ }^{3), 4)}$ と同じように褶曲した 形態のものが観察され柔軟性をもつとみられたが，多くはクリ ソタイル粒子と比べて直線的な形態であった．この形態は同じ 角閃石族系のクロシドライトと類似していた2).ただし，この 吹き付けアモサイトの繊維径にはばらつきがみられ，太いもの では10ミクロンに達するものもみられたが，多くの繊維粒子の 径はサブミクロンから数ミクロンであった.

まず始めに，吹き付けアモサイトを加熱した場合の性状の変 化について調べた. 図 3 に, 吹き付けアモサイトを $500^{\circ} \mathrm{C}$ から $1400^{\circ} \mathrm{C}$ 屯での各温度で 3 時間加熱した場合の, 試料の結晶相の 変化を示した. 比較のために, 未加熱試料の XRD 分析結果も

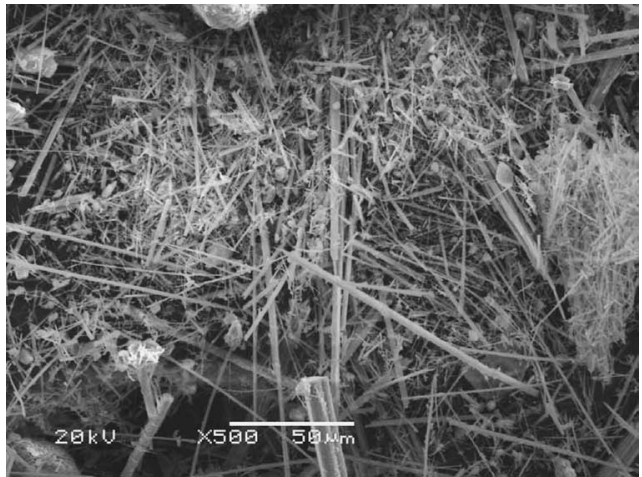

Fig. 2. SEM photograph of sprayed amosite.
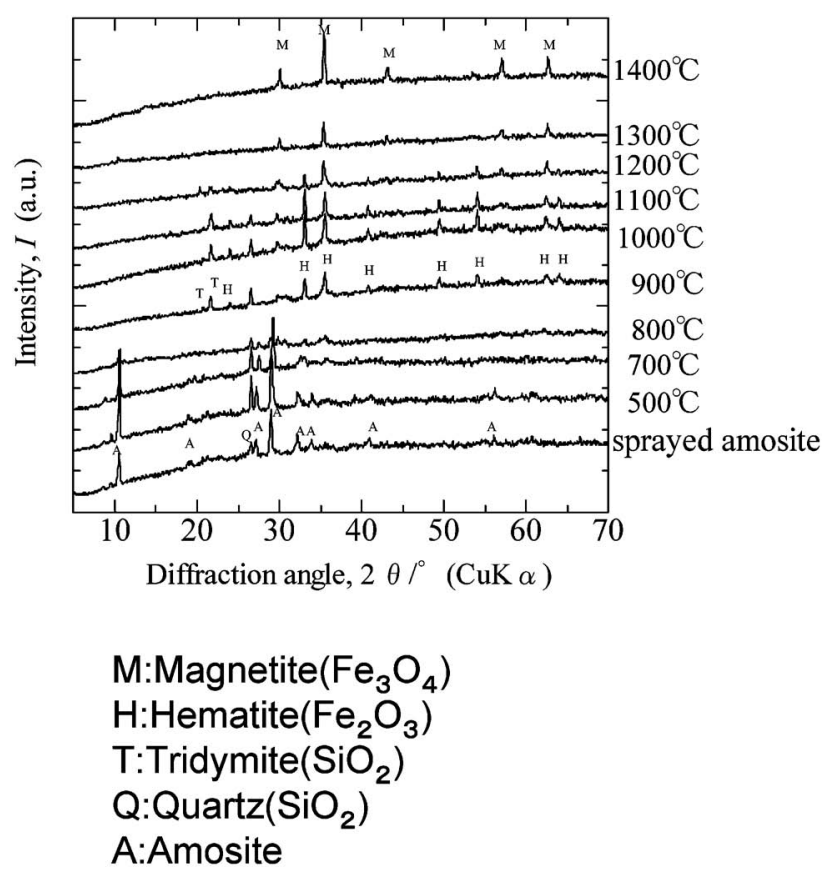

Fig. 3. XRD patterns of sprayed amosite with and without heating at $500-1400^{\circ} \mathrm{C}$ for $3 \mathrm{~h}$.

示した. $2 \theta=26.7^{\circ}$ 付近のピークを除くアモサイトの回折線ピー クは $800^{\circ} \mathrm{C}$ な゙は検出され, $900^{\circ} \mathrm{C}$ では消滅した.この $2 \theta=26.7^{\circ}$ 付近のピークは骨材として加えられた $\mathrm{SiO}_{2}$ (Quartz) とみられ,

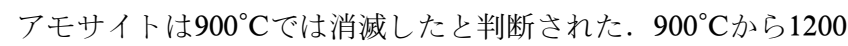
${ }^{\circ} \mathrm{C}$ で加熱処理をした試料からは, $\mathrm{SiO}_{2}$ (Quartz, Tridymite), $\mathrm{Fe}_{2} \mathrm{O}_{3}$ (Hematite) が同定された. $1300^{\circ} \mathrm{C}$ 抢よ゙ $1400^{\circ} \mathrm{C} て ゙$ 熱処 理をした試料からは, 主に $\mathrm{Fe}_{3} \mathrm{O}_{4}$ (Magnetite) が同定された. 概観上は, 加熱により試料は赤茶色に変化し, 加熱温度の上昇 に伴って黒味が増す傾向がみられた。これは $\mathrm{Fe}_{2} \mathrm{O}_{3} や \mathrm{Fe}_{3} \mathrm{O}_{4}$ の 酸化鉄系の析出による呈色とみられた。ささらに $1300^{\circ} \mathrm{C}$ までの加 熱では繊維状組織が肉眼で確認できたが， $1400^{\circ} \mathrm{C} て ゙$ 加熱された 場合, 試料は溶融したとみられ, 繊維状粒子は肉眼では全く観 察されなくなった。

図 4 には, $900^{\circ} \mathrm{C}, 1100^{\circ} \mathrm{C}, 1300^{\circ} \mathrm{C}$ おび $1400^{\circ} \mathrm{Cで}$ 加熱した吹 き付けアモサイトの微細形態を, SEM で観察した結果を示し た. $900^{\circ} \mathrm{C} て ゙$ 熱処理をした試料では，一部は融解したとみられ る䋊維状粒子の癒着が観察された. $1100^{\circ} \mathrm{Cで}$ 加熱された試料で 

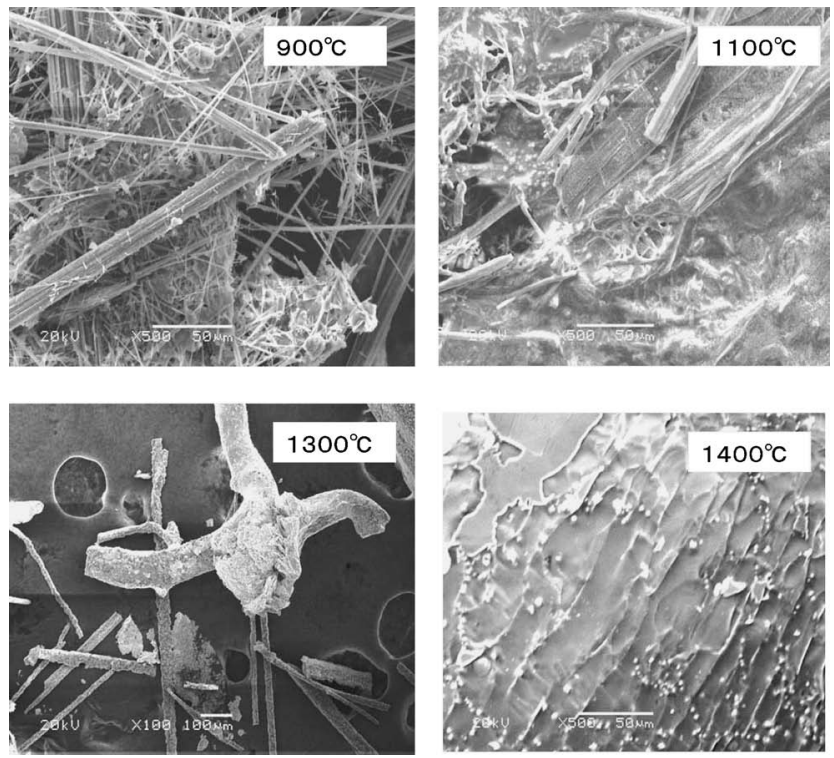

Fig. 4. SEM photographs of sprayed amosite after heating at 900 , 1100,1300 and $1400^{\circ} \mathrm{C}$ for $3 \mathrm{~h}$.

は加熱中溶融状態にある粒子が大半とみられた． $1300^{\circ} \mathrm{C} の$ 加熱 では，粒子の細いものはすべて溶融し繊維径の大きい粒子のみ が残留した. $1400^{\circ} \mathrm{C} て ゙$ 加熱された場合, 完全に溶融し繊維状粒 子は全く観察されなくなった.アモサイトの融点は $\left.1399^{\circ} \mathrm{C}^{6}\right)$ で あるが，セメント成分粒子が共存するため, 部分的に融点が低 下したと考えられる. 吹き付けクロシドライトの場合は $1200^{\circ} \mathrm{C}$ の温度で完全に溶融した ${ }^{2)}$ のに対し, 吹き付けアモサイトの 完全な融解に要した温度は $1400^{\circ} \mathrm{C}$ であり, 比較すると $200^{\circ} \mathrm{C}$ 高 かった. 角閃石族系のアスベスト単相の融点を比較した場合, クロシドライト $\left(\mathrm{Na}_{2}\left(\mathrm{Fe}^{2+}<\mathrm{Mg}\right)_{3}\left(\mathrm{Fe}^{3+}\right)_{2} \mathrm{Si}_{8} \mathrm{O}_{22}(\mathrm{OH})_{2}\right)$ は, 結 晶構造中に $\mathrm{Na}$ を含んで打り, このアルカリの含有によりクロ シドライトの融点はアモサイトに比べて下がり, $1194^{\circ} \mathrm{C}^{6)}$ に なったとみられる. セメント成分と共存する吹き付け材料とし て利用された場合も, この融点の差が完全融解するのに必要々 された温度の差として現れたものと考えられた．ただし，アモ サイトもクロシドライトと同様, セメント成分粒子と共存する 吹き付け材料として使用された場合でも，それぞれ単相の場合 の融点付近に至るまでは, 部分的であるが繊維状の粒子が残留 することが分った.

\section{2 被粉砕性}

これまで，クリソタイルおよびクロシドライトの被粉砕性の 評価に要した処理時間は最大 300 秒 2 ,3) であったので, 吹き付け アモサイトの場合も，加熱処理後に乳鉢で300秒間粉砕し，そ の被粉砕性について調べた. 図 5 に, $900^{\circ} \mathrm{C}, 1000^{\circ} \mathrm{C}, 1100^{\circ} \mathrm{C} て ゙$ 熱処理後粉研した試料の, SEM による微細組織観察結果を示 した。これらの試料は，XRD 分析ではアモサイトが検出され なくなったものである. 比較のために，未加熱試料を粉砕した 後の SEM 観察結果の写真も示した. クロシドライト同様に,

アモサイトの場合も, クリソタイルと違って未加熱試料でも粉 砕され粒子が小さくなったが，アスペクト比で 3 以下の粒子に することはほとんど不可能とみられた．しかしながら，加熱す ることにより繊維状粒子の被粉砕性が向上することが確認でき た．それは特に, 繊維の長さ方向に対して効果がみられた。し かしながら， $900^{\circ} \mathrm{C}$ および $1000^{\circ} \mathrm{C} て ゙$ 加熱した試料からは，粉砕 後も繊維長で10 $\mu \mathrm{m}$ を超える繊維状（柱状）粒子が多く観察さ
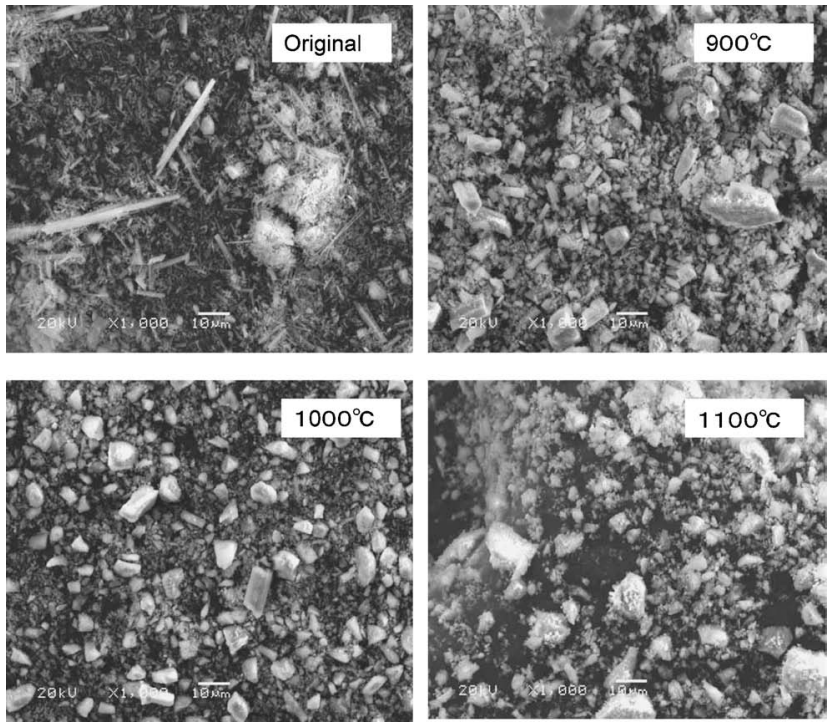

Fig. 5. SEM photographs of sprayed amosite with and without heating at 900,1000 and $1100^{\circ} \mathrm{Cfor} 3 \mathrm{~h}$ after grinding in a mortar $(300 \mathrm{~s})$.
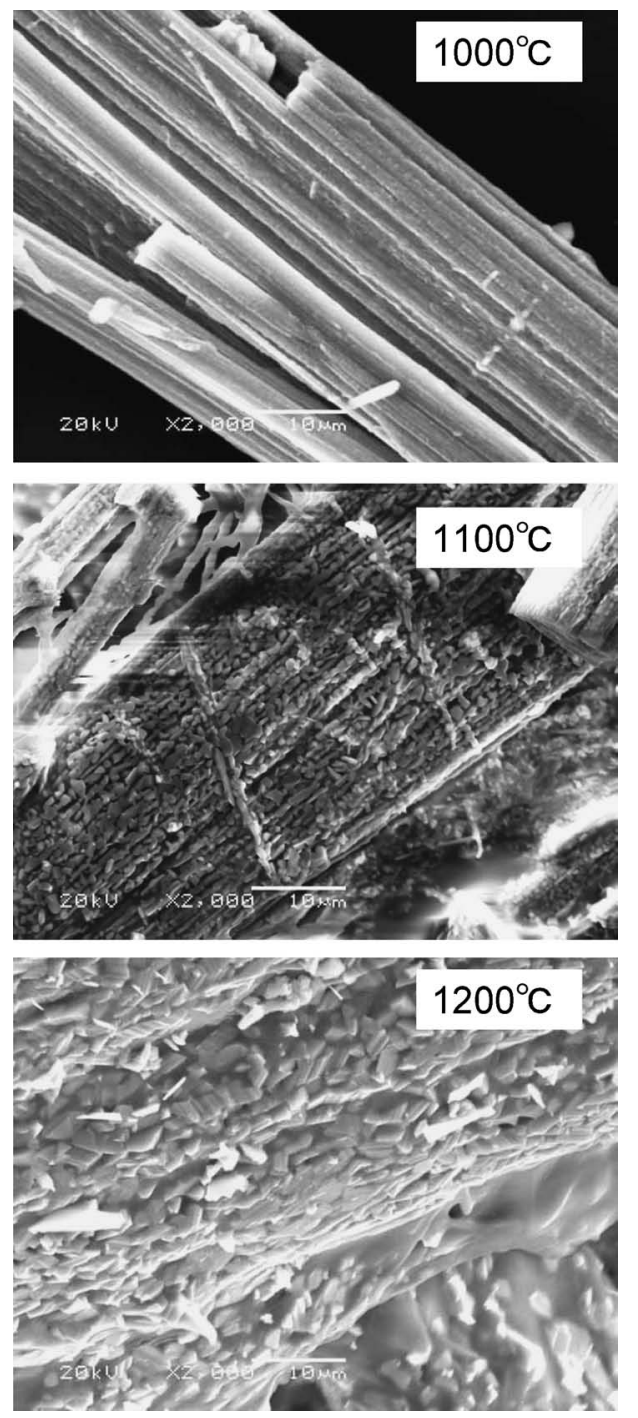

Fig. 6. SEM photographs of the surface of amosite after heating at 1000,1100 and $1200^{\circ} \mathrm{C}$ for $3 \mathrm{~h}$. 

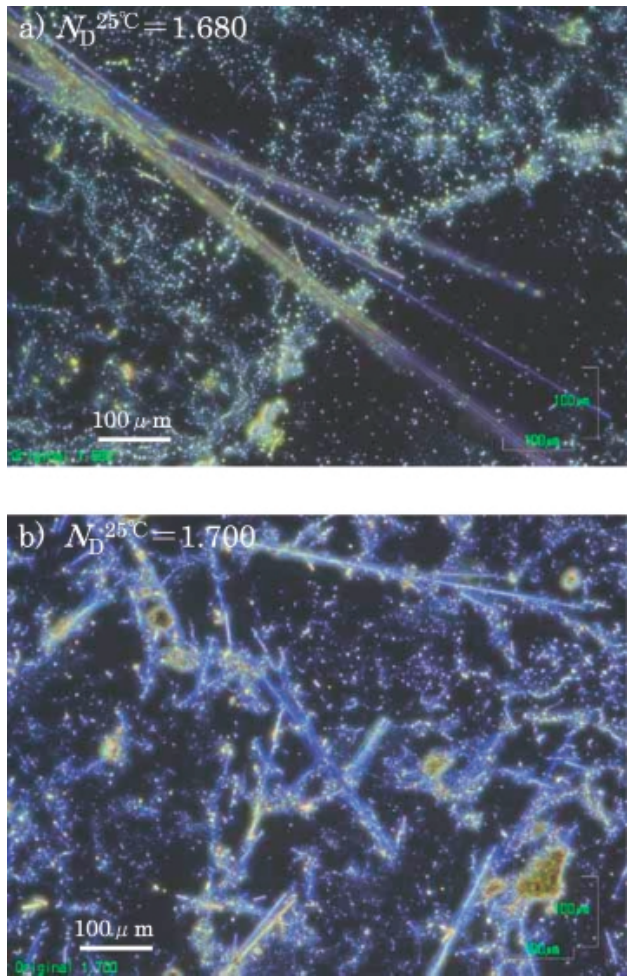

Fig. 7. Phase-contrast micrographs of sprayed amosite with (a) $N_{\mathrm{D}}^{25^{\circ} \mathrm{C}}=1.680$, (b) $N_{\mathrm{D}}{ }^{25^{\circ} \mathrm{C}}=1.700$.

れた，そして，アスペクト比においては 3 を超える粒子も観察 されたが，その被粉砕性は向上して抢り，粉砕時間のさらなる 延長によりアスペクト比を 3 より小さくすることは可能とみら れた. $1100^{\circ} \mathrm{Cで}$ 熱処理をした試料においては繊維状（柱状）粒 子が観察されず, アスペクト比で 3 未満にまで粉砕されている とみられた。この粒子は形状から JIS 規格上無害化されたとい える. 図 6 に，1000 $1200^{\circ} \mathrm{C}$ で加熱した試料の，繊維状粒子表 面をSEM 観察した結果を示した。繊維状粒子の破壊が容易に なった $1100^{\circ} \mathrm{C} て ゙$ 熱処理した試料では, 表面に新たに析出した

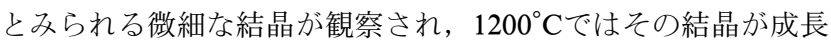
していた. 図 3 より, 熱処理温度が上昇するにつれて主結晶が $\mathrm{Fe}_{2} \mathrm{O}_{3}$ から $\mathrm{Fe}_{3} \mathrm{O}_{4}$ に変化していくことが分かる.このことより, 図 6 にみられる熱処理温度の上昇とともに繊維状粒子表面で観 察された結晶は， $\mathrm{Fe}_{3} \mathrm{O}_{4}$ と考えられた。この $\mathrm{Fe}_{3} \mathrm{O}_{4}$ 結晶の析出 およびその成長により繊維状粒子結晶は機械的に脆くなるとみ られ，繊維状粒子はより微細な粒子にまで粉砕されたと考えら れた.

\section{3 加熱アモサイトの位相差顕微鏡観察}

図 7 は, 未加熱の吹き付けアモサイトの位相差顕微鏡観察写 真である. 図 8 および図 9 は, $500^{\circ} \mathrm{C}$ 抢よび $700^{\circ} \mathrm{C} て ゙ ~ 3$ 時間加熱 処理した吹き付けアモサイトを位相差顕微鏡観察した結果であ る. 未加熱の試料では， $N_{\mathrm{D}}{ }^{25^{\circ} \mathrm{C}}=1.680$ の浸液で分散染色した場 合には桃色に, $N_{\mathrm{D}}{ }^{25^{\circ} \mathrm{C}}=1.7000$ 浸液で分散染色した場合には青 色に呈色しており，この分散染色状態をもってアモサイトと判 定された. 図 8 に示された $500^{\circ} \mathrm{C} て ゙$ 加熱した吹き付けアモサイ 卜の場合, アモサイト特有の分散染色を示す粒子も観察された が， $N_{\mathrm{D}}{ }^{25^{\circ} \mathrm{C}}=1.700$ の浸液に浸漬した場合，青色ではなく象牙色 （橙色）に呈色した繊維状粒子がところどころ観察された. 図 9 に示された $700^{\circ} \mathrm{C}$ 場合には, ほとんどの粒子がアモサイ 卜特有の分散染色, 特に $N_{\mathrm{D}}{ }^{25^{\circ} \mathrm{C}}=1.700$ の場合の青色を示さなく
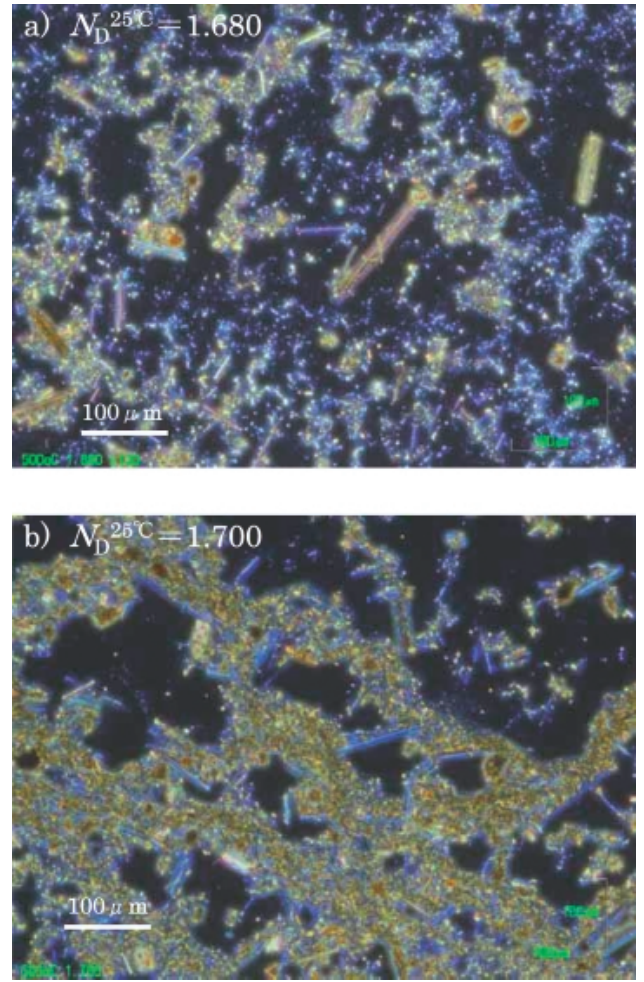

Fig. 8. Phase-contrast micrographs of sprayed amosite with (a) $N_{\mathrm{D}}^{25^{\circ} \mathrm{C}}=1.680$, (b) $N_{\mathrm{D}}{ }^{25^{\circ} \mathrm{C}}=1.700$ after heating at $500^{\circ} \mathrm{C}$ for $3 \mathrm{~h}$.
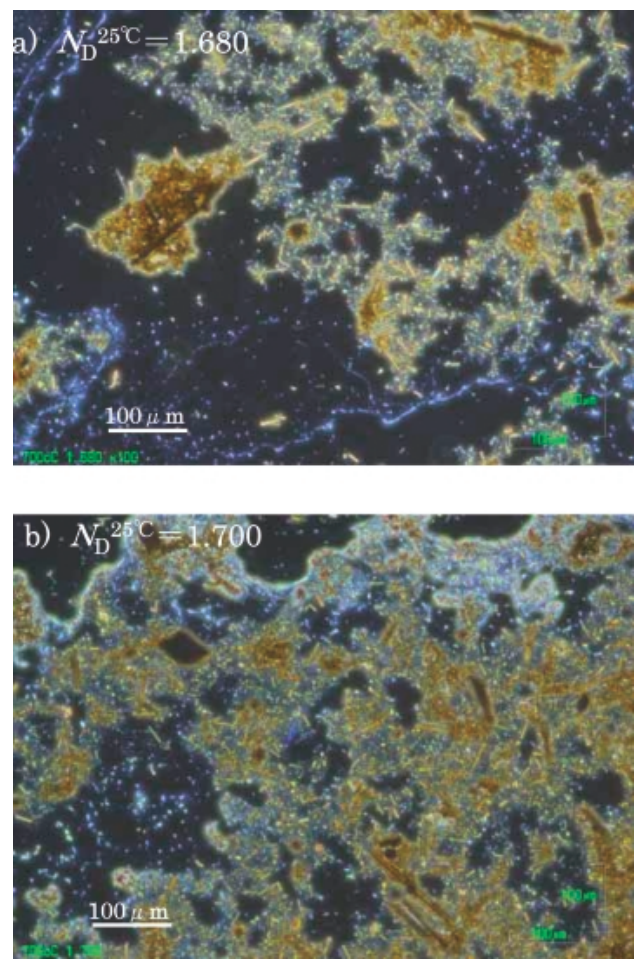

Fig. 9. Phase-contrast micrographs of sprayed amosite with (a) $N_{\mathrm{D}}^{25^{\circ} \mathrm{C}}=1.680$, (b) $N_{\mathrm{D}}^{25^{\circ} \mathrm{C}}=1.700$ after heating at $700^{\circ} \mathrm{C}$ for $3 \mathrm{~h}$.

なった.しかし,これらの繊維状粒子は, 図 3 の XRD 分析結 果よりアモサイトとみられた。このように加熱アモサイトが特 有の分散染色を示さなくなった原因としては, 加熱によりアモ 
サイト粒子表面に新たな層が析出し，アモサイト粒子表面で の屈折率が変化したことが考えられる．加熱により表面に析 出した層は, 図 3 の結果から加熱後の試料中に検出されるよう になったこと, および試料が概観上茶色く変化したことから $\mathrm{Fe}_{2} \mathrm{O}_{3}$ と推定された.この $\mathrm{Fe}_{2} \mathrm{O}_{3}$ の析出により, アモサイト粒 子表面での屈折率が変化し, 判定用に浸漬した浸液の屈折率々 の間に差が生じて特有の呈色（分散染色）反応を示さなくなっ たと考えられる。これは同じ角閃石族系のクロシドライトを加 熱処理した場合にもほぼ同様の結果が得られた ${ }^{2)}$. 以上の結果 から，溶融しない比較的低温で加熱された角閃石族系のアスベ ストの場合，位相差顕微鏡での評価を可能にするためには，ア スベスト繊維状粒子表面に析出する $\mathrm{Fe}_{2} \mathrm{O}_{3}$ 層を何らかの方法に より除去することが必要と考えられる.

\section{4. まとめ}

XRD 分析結果から，吹き付けアモサイトを加熱した場合， $900^{\circ} \mathrm{C}$ で 3 時間加熱した試料からはアモサイト結晶は消滅した. 位相差顕微鏡を用いた分散染色法による評価では， $500^{\circ} \mathrm{C}$ の低 温で加熱したアモサイト繊維状粒子中には検出されなくなる粒 子が生じ始めた。 $700^{\circ} \mathrm{C}$ 場合には, ほとんどの粒子がアモサ イトであると判定できなくなった。加熱された角閃石族系アス ベスト粒子は表面に $\mathrm{Fe}_{2} \mathrm{O}_{3}$ とみられる酸化鉄系の析出物が生 じ，位相差顕微鏡を用いた分散染色法により評価が出来なくな
るので注意が必要である．被粉砕性においては，同じ角閃石族 系のクロシドライトと同様に未加熱のアモサイト繊維状粒子も 小さく粉砕される傾向を示したが，粉砕処理のみで粒子のアス ペクト比を 3 より小さくすることは難しい，加熱された場合に は被粉砕性は向上し， $1100^{\circ} \mathrm{C}$ で加熱された場合に残存する緎維 粒子は，アスペクト比で 3 未満の粒子にまで比較的容易に粉砕 できた.

\section{References}

1) S. Hashimoto, A. Okuda, A. Kambayashi, H. Awaji and K. Fukuda, J. Ceram. Soc. Japan, 114, 716-718 (2006) [in Japanese].

2) S. Hashimoto, A. Okuda, A. Kambayashi, S. Honda, H. Awaji and K. Fukuda, J. Ceram. Soc. Japan, 114, 1150-1154 (2006) [in Japanese].

3) S. Hashimoto, and A. Yamaguchi, J. Ceram. Soc. Japan, 113, 312-316 (2005) [in Japanese].

4) S. Hashimoto and A. Yamaguchi, J. Ceram. Soc. Japan, 113, 804-807 (2005) [in Japanese].

5) S. Hashimoto, H. Takeda, A. Okuda, A. Kambayashi, S. Honda, H. Awaji and K. Fukuda, J. Ceram. Soc. Japan, 115, 290-293 (2007) [in Japanese].

6) R. W. Winson, “Asbestos," 4th ed., Ed. by S. J. Lefond, Industrial Minerals and Rocks (1975) pp. 384-385. 